\title{
Osteocalcin: A New Biomarker for Non Alcoholic Fatty Liver Disease (NAFLD) in Children and Adolescents
}

\author{
Hasan Tarek Abd-Allah Ebrahim ${ }^{1 *}$ and Eman Gamal El-Behery ${ }^{2}$ \\ 1Benha Teaching Hospital, Benha City, Qualubia Governate, Egypt \\ 2Department of Clinical Pathology, Benha Faculty of Medicine, Benha University, Benha City, Qualubia Governate, Egypt
}

\begin{abstract}
Background: Nonalcoholic fatty liver disease (NAFLD) is a common liver disease in adults but uncommon in Pediatrics. Patients with chronic liver disease are at increasing risk of developing metabolic bone disease which may be attributed to decreased Osteocalcin which is involved in bone extracellular matrix mineralization.
\end{abstract}

Aim of the work: was to measure serum osteocalcin levels in children and adolescents with NAFLD and to investigate the relationship with variables degrees of NAFLD.

Materials and methods: This study was carried out upon 60 children with NAFL detected by abdominal ultrasonography. Forty apparently healthy children, matched for age, sex and body mass index (BMI) were chosen as controls. They were subjected to history taking, clinical examination, investigations included liver function tests, fasting serum glucose and insulin levels, Homeostasis Model Assessment method of Insulin Resistance (HOMA-IR), serum osteocalcin level and abdominal Ultrasonography to assess semiquantitavely the degree of steatosis.

Results: Mean serum osteocalcin level was significantly lower in patients than in controls. Mean serum level of ALT, total cholesterol and triglycerides, fasting insulin and HOMA-IR were markedly increases as the hepatic steatosis advancing in severity. There was a parallel decrease of mean serum osteocalcin level with advancing the degree of hepatic steatosis by ultrasound. Serum osteocalcin levels were inversely correlated with the values of W/H ratio, fasting insulin and HOMA-IR.

Conclusions: NAFLD had lower serum levels of osteocalcin compared to controls. It were inversely associated with the degrees of steatosis so can considered as a biomarker for severity NAFLD in pediatric age.

Keywords: Osteocalcin; Non-alcoholic fatty liver disease; Children

\section{Background}

Nonalcoholic Fatty Liver Disease (NAFLD) is a common liver disease in adults but uncommon in Pediatrics. Obesity is increasing worldwide at a dramatic speed among children and adolescents. NAFLD was estimated to affect up to one third of obese children [1]. NAFLD ranges from accumulation of fat in the liver (Hepatosteatosis) that may be accompanied by inflammation (Steatohepatitis) to necrosis, fibrosis and even cirrhosis resembling alcoholic hepatitis in the absence of alcoholic abuse [1]. Paralleling the increasing prevalence of obesity in the pediatric population, NAFLD is expected to become one of the most common causes of liver diseases in obese children and young adults [1]. NAFLD is mainly associated with obesity, diabetes mellitus and hypertension which are the main features of the metabolic syndrome. The pathogenesis of NAFLD is poorly understood. The "multi-hit" theory suggests that in the first "hit", insulin resistance leads to the accumulation of fat within hepatocytes by lipolysis and hyperinsulinemia. The second "hit" mitochondrial release of reactive oxygen species (ROS), lipid peroxidation and cytokine induction [2]. In addition, recent data suggest a potential role for leptin hormone in the pathogenesis of non-alcoholic Steatohepatitis (NASH) by inducing dephosphorylating of insulin-receptor substrate [2]. Patients with chronic liver disease are at increasing risk of developing metabolic bone disease [2]. Which may be attributed to decreased osteocalcin (bone gla protein) which is involved in bone extracellular matrix mineralization [3]. Recent studies suggest that serum osteocalcin plays a key role in the pathogenesis of insulin resistance (IR) as experimentally, osteocalcin-gene deficiency exhibited metabolic syndrome in form of increased fat mass, IR and glucose intolerance [3]. There are few studies, mostly reported in adults that have explored the association between osteocalcin and NAFLD. This prompted us to investigate this relationship in children and adolescents with NAFLD.
The aim of the work was to measure serum osteocalcin levels in children and adolescents with NAFLD and to investigate the relationship between serum osteocalcin levels and both the degree and the clinico-laboratory variables of NAFLD.

\section{Materials and Methods}

\section{Design of the study and setting}

This study was carried out upon 60 children and adolescents diagnosed as NAFL which based on the findings of hepatic steatosis detected by abdominal ultrasonography. Their ages ranged from 5-17 years with a mean value of $10.6 \pm 2.7$ years who were attending the outpatient clinics and inpatient wards of Pediatric Department of Benha Teaching Hospital in the period from July 2015 to July 2017. Forty apparently healthy children, with normal liver function tests and normal liver examination by ultrasonography, matched for age, sex and body mass index (BMI) were chosen as controls. The study was conducted after approval from the ethical committee of the Faculty of Medicine, Benha University and informed oral or written parental consents.

*Corresponding author: Dr. Hasan Tarek Abd-Allah Ebrahim, MD Pediatrics, Consultant Pediatrician, Benha Teaching Hospital, Benha City, Qualubia Governate, Egypt, Tel: 201208136076; E-mail: mgamsy@gmail.com

Received September 04, 2017; Accepted September 09, 2017; Published September 16, 2017

Citation: Ebrahim HT, El-Behery EG (2017) Osteocalcin: A New Biomarker for Non Alcoholic Fatty Liver Disease (NAFLD) in Children and Adolescents. Clin Med Biochem 3: 133. doi:10.4172/2471-2663.1000133

Copyright: (C) 2017 Ebrahim HT, et al. This is an open-access article distributed under the terms of the Creative Commons Attribution License, which permits unrestricted use, distribution, and reproduction in any medium, provided the original author and source are credited. 


\section{Inclusion criteria}

Children and adolescents with overweight or simple obesity who were diagnosed as NAFL by abdominal ultrasonography.

\section{Exclusion criteria}

-Patients with known causes of fatty liver, e.g., diabetes mellitus, glycogen storage disease and or Wilson's disease.

-Patient with syndromatic obesity.

-Patients with viral hepatitis $\mathrm{B}$ or $\mathrm{C}$ by performing serological markers (HBs Ag, Anti $\mathrm{HBc} \mathrm{Ab}$ and HCV Ab).

-Patients receiving long term use of drugs which may cause steatosis or affect bone metabolism, e.g., glucocorticoids.

All participants included in this study were subjected to the following:

- Full history taking

- Through clinical examination which included

Anthropometric measurements including weight, height, BMI, waist circumference (WC), hip circumference (HC) and waist-to-hip ratio (WHR). They were obtained by using standardized equipments following the recommendations of the International Biological program [4]. Each measurement was recorded as the mean of three consecutive readings. The instruments were periodically checked for accuracy and standardization.

Body weight was measured by using Seca scale which was set on a hard, flat and uncarpeted surface. The child should be in light clothes and no shoes were worn, stood straight, calm on the scale, hands close to the trunk. The reading of weight was obtained in kilogram unit to the nearest 0.1 kilogram [5].

Body height was measured by using Harpenden stadiometer which with the same precautions as discussed before. The back of child should be against the scaled board of the stadiometer with the buttocks, back and the occiput touching the stadiometer. The child's eyes should face forward, knees kept unbent, arms close to the trunk and heels together. A special piece of the stadiometer was descended on the highest point of the head without pressure. The reading of height was obtained in meter unit to the nearest 0.1 centimeter [5].

Body mass index (BMI) was calculated according to the known formula:

$$
B M I=\frac{\operatorname{Weight}(\mathrm{kg})}{\operatorname{Height}\left(\mathrm{m}^{2}\right)}
$$

We interpret BMI according to the Egyptian Growth Charts (2002). All the participants had a body mass index (BMI) that was above the $85^{\text {th }}$ percentile for their age and sex, based on the national reference data. Children were defined as overweight if their BMI was equal to or above $85^{\text {th }}$ percentile and as obese if BMI was equal to or above $95^{\text {th }}$ percentile [6].

Waist circumference was measured at the level midway between the lowest rib margin and the iliac crest [7].

Hip circumference was measured at the widest level over the greater trochanters in a standing position, by the same examiner.

Waist-to hip (W/H) ratio was calculated. WHR was considered abnormal if its value exceeds 0.86 . Values of WC and $\mathrm{HC}$ were plotted on American growth curves [2,4,7]. Patients with WHR values exceeded 0.86 were considered abnormal.

\section{- Laboratory investigations}

Liver function tests included total and direct serum bilirubin levels, alanine aminotransferase (ALT), aspartate aminotransferase (AST), alkaline phosphatase (ALP), total serum protein, serum albumin, prothrombin time (PT) and serological markers (HBs Ag, Anti $\mathrm{HBc}$ $\mathrm{Ab}$ and HCV Ab) [8].

Lipid profile included total serum cholesterol, high density lipoproteins cholesterol (HDL-C), low density lipoprotein cholesterol (LDL-C) and triglycerides (TG) [9]. Fasting serum glucose level [10]; Fasting serum insulin level [11]. Homeostasis Model Assessment method of Insulin Resistance (HOMA-IR) for evaluation of insulin resistance was calculated as follow:

HOMA $=\frac{\text { Fasting serum glucose }[\text { mmol / L }] X \text { fasting serum insulin }[\mu \mathrm{U} / \mathrm{ml}]}{22.5}$

(Values $\geq 3$ indicating insulin resistance);

Measurement of serum osteocalcin level [12].

Sampling: Two samples of blood were taken between the hours of 8 and 10 in the morning after 8 hours fasting. The first was $5 \mathrm{ml}$ left to clot at $2-8^{\circ} \mathrm{C}$ and then the serum was separated using centrifugation then stored frozen at $-20^{\circ} \mathrm{C}$ till time of analysis. This sample was used to analyze liver function tests and fasting blood glucose level, lipid profile and osteocalcin. The second sample for performing fasting serum insulin level, $1 \mathrm{ml}$ of blood left to clot at $2-8^{\circ} \mathrm{C}$ and then the serum was separated using centrifugation.

Determination of serum insulin by enzyme linked immunosorbent assay (ELISA) method, using insulin ELISA kit which is a solid phase enzyme-linked immunosorbent assay based on the sandwich principle, Sigma Company [11].

Determination of serum osteocalcin in human serum: [12] by an immunoassay in which a sample of the serum or plasma containing the h-osteocalcin to be determined is incubated, Reference values for Pediatric age:

\section{5-9 years: $47-142 \mathrm{ng} / \mathrm{ml}$}

10-13 years: $49-167 \mathrm{ng} / \mathrm{ml}$.

Abdominal ultrasonography: US to confirm diagnosis of liver fatty infiltration and to assess semiquantitavely the degree of steatosis. Liver ultrasound was carried out by using a convex 3.5-5.0 $\mathrm{MHz}$ probe. Sagittal hepatic sections that encompassed longitudinal images of the right liver lobe and the ipsi-lateral kidney were obtained. Moreover, hepatic US can provide a good estimate of the degree or extent of hepatic steatosis present based on a series of US characteristics including hepatorenal echo contrast, liver echogenicity, visualization of intrahepatic vessels and visualization of liver parenchyma and the diaphragm [13]. The diagnosis of hepatic steatosis was made on the basis of characteristic sonographic features: increased echogenicity of liver; increased liver contrast compared to kidney, vascular blurringmainly of portal veins, attenuation of echogenic level in deep seated area [13].

\section{Grading of nonalcoholic fatty liver on ultrasonography}

Grade I: Minimal diffuse increase in the fine echoes. Liver appears bright compared to the cortex of the kidney.

Grade II: Moderate diffuse increase in the fine echoes. Slightly 
impaired visualization of the intrahepatic vessels and diaphragm.

Grade III: Marked increase in the fine echoes. Poor or no visualization of intrahepatic vessels and diaphragm and poor penetration of the posterior segment of the right lobe of the liver [14].

\section{Statistical analysis}

Statistical presentation and analysis of the present study was conducted, using the mean, standard error, student t- test, Chi-square, Linear correlation coefficient ( $r$ ), ROC curve Test and Analysis of variance (ANOVA) tests by SPSS V17. Unpaired Student T-test was used to compare between two groups in quantitative data. Chi-square hypothesis that the row and column variables are independent, without indicating strength or direction of the relationship. Pearson chisquare and likelihood-ratio chi-square. Fisher's exact test and Yates' corrected chi-square are computed for $2 \times 2$ tables. Linear Correlation Coefficient ( $r$ ) was used for detection of correlation between two quantitative variables in one group. Analysis of variance (ANOVA) test was used for comparison among different times in the same group in quantitative data. Significance was adopted at $\mathrm{p}<0.05$ for interpretation of results of tests of significance [15].

\section{Results}

Patients enrolled in this study were classified according to BMI into $6(10 \%)$ were overweight and $54(90 \%)$ were obese. They were sonographically sub grouped into 3 grades: $40(66.7 \%)$ patients had grade I, 16 (26.7\%) had grade II and 4 (6.7\%) had grade III steatosis.

Table 1 summarized demographic data of studied patients and controls, there was no significant difference between patients and controls as regard age, sex, Out of the 60 studied patients, 40 female (66.7\%) and 20 male (33.3\%). Mean value of waist and hip circumferences was significantly higher in patients than controls. Mean value of weight, height, BMI and WHR was stastically insignificant between patients and controls. Hepatomegaly, hypertension and acanthosis nigricans were found in $14(23.33 \%), 16(26.6 \%)$ and 10 (16.67\%) of the studied patients respectively. Splenomegaly, ascites or

\begin{tabular}{|c|c|c|c|c|c|}
\hline & & $\begin{array}{c}\text { Group I } \\
(n=60)\end{array}$ & $\begin{array}{c}\text { Group II } \\
(n=60)\end{array}$ & $\begin{array}{c}\text { Statistical } \\
\text { test }\end{array}$ & $\mathrm{P}$ value \\
\hline \multirow{2}{*}{$\begin{array}{c}\text { Age } \\
\text { (years) }\end{array}$} & Range & $5-17$ & $5-15$ & \multirow{2}{*}{1.7} & \multirow{2}{*}{0.16} \\
\hline & Mean \pm SD & $10.6 \pm 2.7$ & $9.1 \pm 3.5$ & & \\
\hline \multirow{2}{*}{ Gender } & $\begin{array}{l}\text { Male: } \\
\text { No (\%) }\end{array}$ & $20(33.3 \%)$ & $24(60 \%)$ & \multirow{2}{*}{3.5} & \multirow{2}{*}{0.06} \\
\hline & $\begin{array}{l}\text { Female: } \\
\text { No }(\%)\end{array}$ & $40(66.7 \%)$ & $16(40 \%)$ & & \\
\hline \multirow{2}{*}{ Weight (kg) } & Range & $33.5-100$ & $27-29$ & \multirow{2}{*}{1.57} & \multirow{2}{*}{0.12} \\
\hline & Mean \pm SD & $72 \pm 19.4$ & $46 \pm 13.9$ & & \\
\hline \multirow{2}{*}{ Height (cm) } & Range & $105.5-159.5$ & $107-154$ & \multirow{2}{*}{1.3} & \multirow{2}{*}{0.22} \\
\hline & Mean \pm SD & $141.6 \pm 15.2$ & $136.6 \pm 11.3$ & & \\
\hline \multirow{2}{*}{ BMI $\left(\mathrm{Kg} / \mathrm{m}^{2}\right)$} & Range & $29.8-48.2$ & $13.4-50.8$ & \multirow{2}{*}{0.29} & \multirow{2}{*}{0.78} \\
\hline & Mean \pm SD & $35.1 \pm 4.6$ & $34.6 \pm 7.9$ & & \\
\hline \multirow{2}{*}{$\begin{array}{l}\text { Waist } \\
\text { circumference } \\
\text { (cm) }\end{array}$} & Range & $76-117$ & $70-98$ & \multirow[b]{2}{*}{5.7} & \multirow{2}{*}{$<0.001^{*}$} \\
\hline & Mean \pm SD & $99.4 \pm 11$ & $82.4 \pm 9.5$ & & \\
\hline \multirow{2}{*}{$\begin{array}{c}\text { Hip } \\
\text { circumference } \\
\text { (cm) }\end{array}$} & Range & $79-137$ & $69-100$ & \multirow{2}{*}{5.6} & \multirow{2}{*}{$<0.001^{*}$} \\
\hline & Mean \pm SD & $105 \pm 14.3$ & $84.5 \pm 9.8$ & & \\
\hline \multirow{2}{*}{$\begin{array}{c}\text { Waist/Hip } \\
\text { circumference } \\
\text { (cm) }\end{array}$} & Range & $0.1-1.1$ & $0.9-1.1$ & \multirow{2}{*}{1.41} & \multirow{2}{*}{0.16} \\
\hline & Mean \pm SD & $0.9 \pm 0.2$ & $0.97 \pm 0.04$ & & \\
\hline
\end{tabular}

BMI: body mass index; $p$ : $p$ values for comparing between the studied groups; *Statistically significant at $p \leq 0.05$

Table 1: Demographic data of the studied groups.

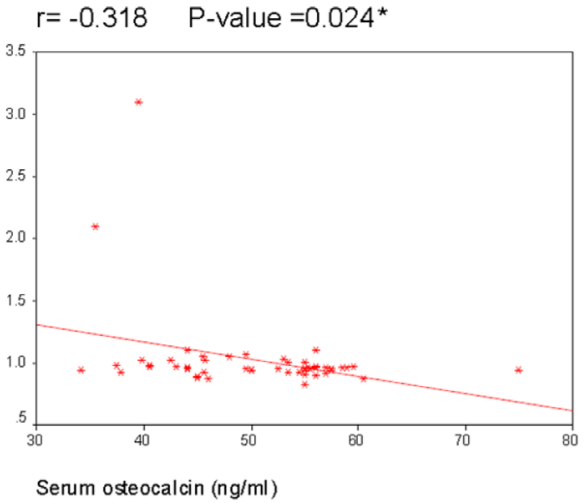

Figure 1: Correlation coefficient between serum osteocalcin and $\mathrm{W} / \mathrm{H}$ ratio in the studied patients.

edema were not detected in any studied patients (Figure 1).

Tables $2 \mathrm{a}$ and $2 \mathrm{~b}$ summarized laboratory data of studied patients and controls; there was no statistically significant difference in $\mathrm{CBC}$, serum creatinine, serum bilirubin, albumin, ALT, AST, HDL or LDL. Mean serum level of total cholesterol, and triglycerides (TG) was significantly higher in patients than control. Mean fasting serum glucose level was significantly higher in patients $(85.7 \pm 9.3 \mathrm{mg} / \mathrm{dl})$ than controls $(79.8 \pm 4 \mathrm{mg} / \mathrm{dl}),(\mathrm{p}=0.009)$ (Figure 2). Mean fasting serum insulin level was significantly higher in patients $(15.5 \pm 2.6 \mu \mathrm{U} /$ $\mathrm{ml})$ than in controls $(14.1 \pm 1.5 \mu \mathrm{U} / \mathrm{ml}),(\mathrm{p}=0.025)$. Mean HOMA-IR value was significantly higher in patients $(3.4 \pm 0.8)$ than in controls $(2.8 \pm 0.3),(\mathrm{p}=0.004)$. Mean serum osteocalcin level in was significantly lower in patients $(48.3 \pm 7.8 \mathrm{ng} / \mathrm{ml})$ than in controls $(52.8 \pm 7.6 \mathrm{ng} / \mathrm{ml})$, $(\mathrm{p}=0.049)$ (Figure 3).

Table 3 compared between demographic and laboratory data of studied patients according to grading of hepatic steatosis. Mean serum level of ALT, total cholesterol and triglycerides was increasing paralleling the severity of steatosis. Mean value of insulin resistance (HOMA-IR) markedly increases as the hepatic steatosis advancing in severity. Mean serum level of total cholesterol and triglycerides was increasing paralleling the severity of steatosis. Mean values of serum level of fasting insulin and insulin resistance (HOMA-IR) increase paralleling the severity of steatosis. Mean level of osteocalcin was (51 \pm $7.32 \mathrm{ng} / \mathrm{ml})$ in grade I, $(44 \pm 5.8 \mathrm{ng} / \mathrm{ml})$ in grade II and $(39.1 \pm 7 \mathrm{ng} / \mathrm{ml})$ in grade III. There was a parallel decrease of mean serum osteocalcin level with advancing the degree of hepatic steatosis by ultrasound. Table 4 compared between Patients with metabolic syndrome (MS) and patients without MS according to laboratory data. Values of HOMAIR and alkaline phosphatase were higher in patients with metabolic syndrome than patients without metabolic syndrome Mean level of serum osteocalcin was lower in patients with metabolic syndrome $(43.850 \pm 9.963 \mathrm{ng} / \mathrm{ml})$ than in patients without metabolic syndrome $(48.965 \pm 7.410 \mathrm{ng} / \mathrm{ml})$ with $\mathrm{p} \leq 0.05$ (Figure 4$)$.

Table 5 summarized correlations between serum osteocalcin and different studied variables in patients. Serum osteocalcin levels were inversely correlated with the values of $\mathrm{W} / \mathrm{H}$ ratio, ALT, triglycerides, fasting insulin and HOMA-IR.

\section{Discussion}

Pediatric NAFLD is considered as a global problem which has been increased in prevalence with the dramatic rise in obesity in children during the past three decades [16]. NAFLD is an important cause of 
Citation: Ebrahim HT, El-Behery EG (2017) Osteocalcin: A New Biomarker for Non Alcoholic Fatty Liver Disease (NAFLD) in Children and Adolescents. Clin Med Biochem 3: 133. doi:10.4172/2471-2663.1000133

Page 4 of 8

\begin{tabular}{|c|c|c|c|c|c|}
\hline & & Group I $(n=60)$ & Group II $(n=60)$ & Statistical test & $P$ value \\
\hline \multirow{2}{*}{ Hemoglobin (gm/dl) } & Range & $9.5-14$ & $12-15$ & \multirow{2}{*}{1.595} & \multirow{2}{*}{0.116} \\
\hline & Mean $\pm S D$ & $11.79 \pm 1.38$ & $12.23 \pm 0.61$ & & \\
\hline \multirow{2}{*}{$\operatorname{TLC}\left(\times 10^{3} / \mathrm{mm}^{2}\right)$} & Range & $4.7-14.9$ & $4.1-13.9$ & \multirow{2}{*}{0.013} & \multirow{2}{*}{0.99} \\
\hline & Mean \pm SD & $8.24 \pm 3.08$ & $8.25 \pm 2.89$ & & \\
\hline \multirow{2}{*}{ Platelets count $\left(\times 10^{3} / \mathrm{mm}^{2}\right)$} & Range & $153-409$ & $159-386$ & \multirow{2}{*}{0.652} & \multirow[t]{2}{*}{0.519} \\
\hline & Mean \pm SD & $252.56 \pm 75.68$ & $266.28 \pm 73.72$ & & \\
\hline \multirow{2}{*}{ Total serum Bilirubin (mg/dl) } & Range & $0.5-1.4$ & $0.5-1.4$ & \multirow{2}{*}{1.263} & \multirow{2}{*}{0.217} \\
\hline & Mean \pm SD & $0.91 \pm 0.27$ & $0.82 \pm 0.26$ & & \\
\hline \multirow{2}{*}{ Serum albumin (gm/dl) } & Range & $3.5-4.5$ & $3.4-4.5$ & \multirow{2}{*}{0} & \multirow{2}{*}{1} \\
\hline & Mean \pm SD & $3.92 \pm 0.29$ & $3.92 \pm 0.32$ & & \\
\hline \multirow{2}{*}{ ALT (U/L) } & Range & $21-40$ & $20-39$ & \multirow{2}{*}{0.398} & \multirow{2}{*}{0.694} \\
\hline & Mean \pm SD & $28.93 \pm 5.77$ & $28.23 \pm 5.65$ & & \\
\hline \multirow{2}{*}{ AST (U/L) } & Range & $24-46$ & $22-41$ & \multirow{2}{*}{1.187} & \multirow{2}{*}{0.245} \\
\hline & Mean \pm SD & $32.63 \pm 5.91$ & $30.57 \pm 5.71$ & & \\
\hline \multirow{2}{*}{ Serum creatinine (mg/dl) } & Range & $0.4-1.2$ & $0.4-1.1$ & \multirow{2}{*}{0.521} & \multirow{2}{*}{0.606} \\
\hline & Mean \pm SD & $0.77 \pm 0.71$ & $0.67 \pm 0.7$ & & \\
\hline
\end{tabular}

ALT: Alanine aminotransferase; AST: Aspartate aminotransferase; $p$ : $p$ values for comparing between the studied groups; *Statistically significant at $p \leq 0.05$ Table 2a: Laboratory characteristics of patients and controls.

\begin{tabular}{|c|c|c|c|c|c|}
\hline & & Group I $(n=60)$ & Group II $(n=40)$ & Statistical test & $P$ value \\
\hline \multirow{2}{*}{ Total cholesterol (mg/dl) } & Range & $87-278$ & $99-240$ & \multirow{2}{*}{2.95} & \multirow{2}{*}{$0.005^{*}$} \\
\hline & Mean \pm SD & $193.4 \pm 41$ & $157.3 \pm 44.5$ & & \\
\hline \multirow{2}{*}{ Triglycerides (mg/dl) } & Range & $60-194$ & $60-180$ & \multirow{2}{*}{2.4} & \multirow{2}{*}{$0.02^{*}$} \\
\hline & Mean \pm SD & $117.2 \pm 365$ & $93.4 \pm 29.3$ & & \\
\hline \multirow{2}{*}{ HDL (mg/dl) } & Range & $20-57$ & $15-59$ & \multirow{2}{*}{0.2} & \multirow{2}{*}{0.8} \\
\hline & Mean \pm SD & $40.8 \pm 11.1$ & $41.4 \pm 11.5$ & & \\
\hline \multirow{2}{*}{ LDL (mg/dl) } & Range & 63-195 & $49-160$ & \multirow{2}{*}{1.67} & \multirow{2}{*}{0.1} \\
\hline & Mean \pm SD & $110.6 \pm 32.4$ & $95.4 \pm 30.2$ & & \\
\hline \multirow{2}{*}{ Fasting serum glucose $(\mathrm{uU} / \mathrm{ml})$} & Range & $69-103$ & $70-85$ & \multirow{2}{*}{2.71} & \multirow{2}{*}{$0.009^{*}$} \\
\hline & Mean \pm SD & $85.7 \pm 9.3$ & $79.8 \pm 4$ & & \\
\hline \multirow{2}{*}{ Fasting insulin ( $\mu \mathrm{u} / \mathrm{ml})$} & Range & $11.6-25.9$ & $12.3-17.5$ & \multirow{2}{*}{2.31} & \multirow{2}{*}{$0.03^{*}$} \\
\hline & Mean \pm SD & $15.5 \pm 2.6$ & $14.1 \pm 1.5$ & & \\
\hline \multirow{2}{*}{ HOMA-IR } & Range & $2.4-6.7$ & $2.5-3.3$ & \multirow{2}{*}{3.05} & \multirow{2}{*}{$0.004^{*}$} \\
\hline & Mean \pm SD & $3.7 \pm 0.8$ & $2.8 \pm 0.3$ & & \\
\hline \multirow{2}{*}{ Serum osteocalcin (ng/ml) } & Range & $34.1-60.5$ & $40.5-74.9$ & \multirow{2}{*}{$2.02-$} & \multirow{2}{*}{$0.05^{*}$} \\
\hline & Mean \pm SD & $48.3 \pm 7.8$ & $52.8 \pm 7.6$ & & \\
\hline
\end{tabular}

P: $p$ values for comparing between the studied groups; $p$. value: patients vs control; LDL-C (low density lipoprotein cholesterol); HDL-C (high density lipoprotein cholesterol).; *: Statistically significant at $p \leq 0.05$

Table 2b: Laboratory characteristics of patients and controls (Cont.).

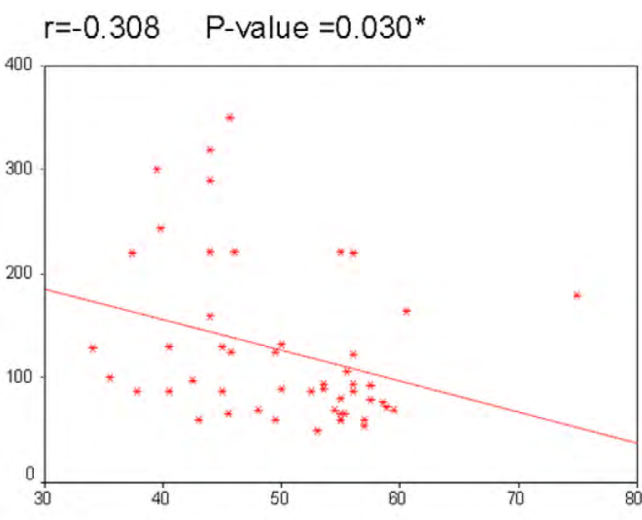

Serum osteocalcin $(\mathrm{ng} / \mathrm{ml})$

Figure 2: Correlation coefficient between serum osteocalcin and triglycerides in the studied patients.
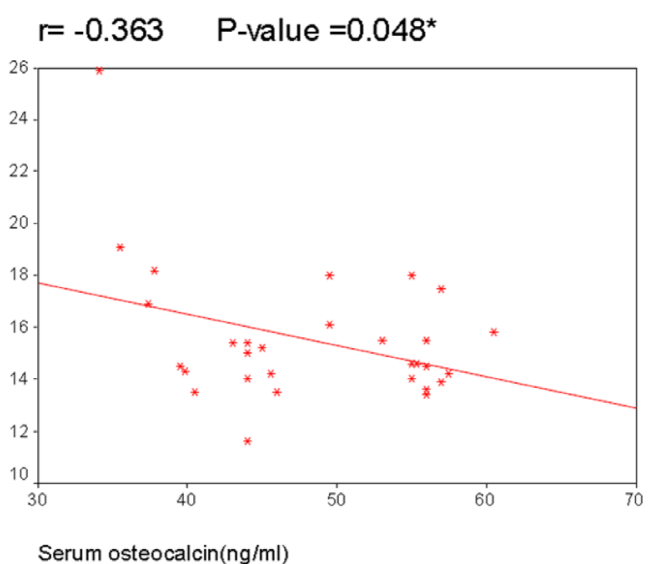

Figure 3: Correlation coefficient between serum osteocalcin and fasting serum insulin in the studied patients. 
Citation: Ebrahim HT, El-Behery EG (2017) Osteocalcin: A New Biomarker for Non Alcoholic Fatty Liver Disease (NAFLD) in Children and Adolescents. Clin Med Biochem 3: 133. doi:10.4172/2471-2663.1000133

Page 5 of 8

\begin{tabular}{|c|c|c|c|c|c|c|}
\hline & & \multirow{2}{*}{ Grade I NAFLD } & \multirow{2}{*}{ Grade II NAFLD } & \multirow{2}{*}{ Grade III NAFLD } & \multicolumn{2}{|c|}{ Statistical test } \\
\hline & & & & & $\mathrm{F}=\mathrm{ANOVA}$ & P value \\
\hline \multirow{2}{*}{ Serum osteocalcin (ng/ml) } & Range & $37.4-60.9$ & $35.5-56$ & $34.1-44$ & \multirow{2}{*}{4.74} & \multirow{2}{*}{0.02} \\
\hline & Mean \pm SD & $50.9 \pm 7.3$ & $44 \pm 5.8$ & $39.1 \pm 7$ & & \\
\hline $\begin{array}{c}\text { Age } \\
\text { (years) }\end{array}$ & Mean \pm SD & $10.3 \pm 2.9$ & $11.9 \pm 1.7$ & $7.8 \pm 1.8$ & 2.3 & 0.12 \\
\hline BMI $\left(\mathrm{Kg} / \mathbf{m}^{2}\right)$ & Mean \pm SD & $34.4 \pm 3.9$ & $36.1 \pm 5.3$ & $38.5 \pm 8.8$ & 1.03 & 0.37 \\
\hline Waist /Hip circumference $(\mathrm{cm})$ & Mean \pm SD & $0.94 \pm 0.1$ & $0.85 \pm 0.3$ & $0.95 \pm 0.01$ & 0.94 & 0.4 \\
\hline ALT (U/L) & Mean \pm SD & $28.5 \pm 9.8$ & $32.8 \pm 11.9$ & $39.5 \pm 17.7$ & 0.23 & $0.02^{*}$ \\
\hline ALP (IU/L) & Mean \pm SD & $244.9 \pm 131.5$ & $244.4 \pm 106.3$ & $400 \pm 70.7$ & 1.83 & 0.18 \\
\hline Total cholesterol (mg/dl) & Mean \pm SD & $186 \pm 41.4$ & $194.5 \pm 25.5$ & $284 \pm 19.8$ & 3.99 & $0.03^{*}$ \\
\hline Triglycerides (mg/dl) & Mean \pm SD & $11131 \pm 32.9$ & $122.8 \pm 47.3$ & $154.5 \pm 21.9$ & 0.32 & $0.01^{*}$ \\
\hline HDL (mg\%) & Mean \pm SD & $43 \pm 9.8$ & $37.5 \pm 12.7$ & $31 \pm 15.6$ & 1.6 & 0.22 \\
\hline LDL (mg\%) & Mean \pm SD & $108 \pm 31.2$ & $108 \pm 34.4$ & $142.5 \pm 38.9$ & 1.04 & 0.37 \\
\hline Fasting insulin ( $\mu \mathrm{u} / \mathrm{ml})$ & Mean \pm SD & $15.3 \pm 1.4$ & $16.4 \pm 2.6$ & $189 \pm 10.1$ & 2.3 & $0.03^{*}$ \\
\hline HOMA-IR & Mean \pm SD & $3.2 \pm 0.5$ & $3.5 \pm 0.03$ & $4.8 \pm 2.8$ & 5.1 & $0.01^{*}$ \\
\hline
\end{tabular}

HOMA-IR: Homeostasis module assessment of insulin resistance; *Significant; $p$ value: patients vs control

Table 3: Comparison between demographic and laboratory data of srudied patients according to grading of hepatic steatosis.

\begin{tabular}{|c|c|c|c|c|c|c|}
\hline \multirow{2}{*}{$\begin{array}{c}\text { Laboratory } \\
\text { findings }\end{array}$} & \multicolumn{2}{|c|}{$\begin{array}{c}\text { Patients without } \\
\text { metabolic } \\
\text { syndrome (No=52) }\end{array}$} & \multicolumn{2}{|c|}{$\begin{array}{c}\text { Patients with } \\
\text { metabolic } \\
\text { syndrome (No=8) }\end{array}$} & \multicolumn{2}{|c|}{ Statistical test } \\
\cline { 2 - 8 } & Mean & SD & Mean & SD & t value & P value \\
\hline ALT (U/L) & 29.2 & 10.6 & 29 & 10.6 & 0.04 & 0.97 \\
\hline AST (U/L) & 30.7 & 9 & 36.5 & 8.6 & -1.2 & 0.24 \\
\hline $\begin{array}{c}\text { Alkaline } \\
\text { Phosphatease } \\
\text { (IU/L) }\end{array}$ & 220.6 & 122 & 379.3 & 56.8 & -2.5 & $0.02^{*}$ \\
\hline $\begin{array}{c}\text { HOMA-IR } \\
\begin{array}{c}\text { Serum } \\
\text { osteocalcin (ng/ } \\
\text { ml) }\end{array}\end{array}$ & 3.3 & 0.5 & 4.1 & 1.8 & -2.2 & $0.04^{*}$ \\
\hline
\end{tabular}

HOMA-IR

Table 4: Comparison between patients with metabolic syndrome and patients without metabolic syndrome according to laboratory data.

$r=-0.381 \quad P$-value $=0.038^{\star}$

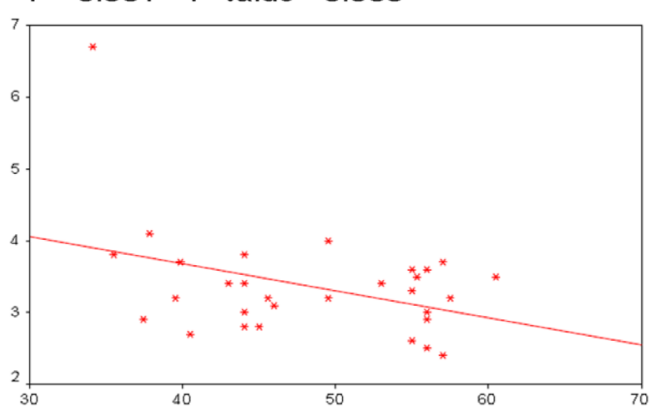

Serum osteocalcin $(\mathrm{ng} / \mathrm{ml})$

Figure 4: Correlation coefficient between serum osteocalcin and HOMA-IR in the studied patients.

chronic liver disease in children.

An Egyptian study gave the prevalence of NAFLD in 38.5\% inobese children and adolescents [17]. Mechanisms behind the reduced BMD in NAFLD are still not completely understood [2]. Currently the information on the relationships between serum osteocalcin and NAFLD is lacking. The present study was designed to analyses the relationship between serum osteocalcin levels and NAFLD in children and adolescents. In our study, we diagnosed NAFLD patient by US which is reliable modality for the screening for fatty liver in clinical

\begin{tabular}{|c|c|c|}
\hline Variable & $\mathbf{r}$ & $\mathbf{p}$ \\
\hline Age (years) & 0.155 & 0.415 \\
\hline BMI (kg/m $\left.{ }^{2}\right)$ & 0.104 & 0.584 \\
\hline W/H ratio & -0.318 & $0.024^{*}$ \\
\hline ALT (U/L) & -0.342 & $0.015^{*}$ \\
\hline ALP (IU/L) & -0.286 & 0.126 \\
\hline Total cholesterol (mg/dl) & -0.108 & 0.571 \\
\hline Triglycerides (mg/dl) -0.308 & -0.308 & $0.03^{*}$ \\
\hline HDL (mg/dl) & 0.078 & 0.683 \\
\hline LDL (mg/dl) & 0.078 & 0.68 \\
\hline Fasting insulin $(\boldsymbol{\mu u} / \mathbf{m l})$ & -0.363 & $0.048^{*}$ \\
\hline HOMA-IR & -0.381 & $0.038^{*}$ \\
\hline
\end{tabular}

*Significant; BMI: body mass index; W/H ratio: Waist to hip ratio; HDL: High Density Lipoprotein; LDL: Low Density Lipoprotein; HOMA-IR: Homeostasis Model Assessment method of Insulin Resistance

Table 5: Correlations serum osteocalcin and different studied variables in patients.

settings. Dasarathy et al. [18] reported that US had a sensitivity of $81 \%$ and a specificity of $98 \%$ in identifying hepatic steatosis. The present study showed that patients and controls had high waist circumference exceeding the $95^{\text {th }}$ percentile. The mean value of waist circumference in NAFLD patients was significantly higher than in those without NAFLD. Waist circumference is considered a surrogate measure of visceral fat and may predict the development of NAFLD in children [19] and considered as integral part of the definition of the metabolic syndrome both in children and adults [20].

This was in agreement with Duarte and Silva [21] study. By ultrasound we observed that $40(66.7 \%)$ of our patients had grade I fatty infiltration, 8 patients $(26.7 \%)$ had grade II and 4 patients $(6.7 \%)$ had grade III fatty liver which was in agreement of study of Duarte and Silva [21] and Papandreou et al. [22]. Hepatic synthetic functions were assessed by measuring serum albumin and prothrombin time values showing no significant difference between patients and controls. These results coincided with that reported by other authors studied obese patients with NAFLD $[23,24]$.

In this study, there was elevation in ALT levels paralleled the advancing grades of grading of NAFL. Previous reports have shown controversial results regarding the correlation between ALT elevation and the presence of hepatic fat on imaging. In the study conducted by Franzese et al. [25], about two thirds of their NAFLD had normal amino transaminases. In the study by Tazawa et al. [26], 18\% of Japanese 
school children with normal ALT levels had ultrasound findings of NASH.

The present work showed a clear evidence of abnormal lipid profile in the studied patients. The mean serum level of total cholesterol and triglycerides was significantly higher in patients than in controls. Also, there was an increase in the mean serum level of total cholesterol and triglycerides with increasing the degree of hepatic steatosis. This results was in agreement with Sartorio et al. [24], El-Karaksy et al. [17] and Duarte and Silva study [26], On the other hand, Papandreo et al. [22] reported that none of their studied obese children with NAFLD had abnormal lipid profile or liver indices.

In the present work, we found that $8(13.3 \%)$ fulfilled the criteria of the metabolic syndrome. This estimated value was lower than that reported in other pediatric studies. Jun-Fen et al. [27] gave a prevalence of metabolic syndrome (MS) of $26 \%$ among their studied obese children and of $40 \%$ in those with NAFLD. The lower incidence of metabolic syndrome in our study may be attributed to the presence of mild and moderate fatty infiltration of the liver in the majority of the currently studied patients (93.3\% in grade I and II versus $6.7 \%$ in grade III steatosis). It is known that the presence of severe steatosis carries a high risk of development of MS [28]. This highlights that NAFLD is closely associated with features of the metabolic syndrome.

In this study, the mean level of fasting serum glucose and insulin was significantly higher in patients with NAFLD than that of controls.

There was an increase in mean level of fasting serum insulin with increasing the degree of hepatic steatosis. Sartorio et al. showed similar results [24] Mean value of insulin resistance, as measured by HOMAIR was markedly higher in the studied patients when compared to controls.

Among the 60 patients with NAFLD, 38 cases (63.3\%) exhibited abnormal HOMA-IR values. We also observed that there was an increase in mean HOMA-IR values with increasing the degree of hepatic steatosis. All patients with grade III and $87.5 \%$ with grade II and $50 \%$ of those with grade I had IR. These results may indicate that insulin resistance, in addition to hyperinsulinemia, occurs early and worsen in children with grade II and III (presumed to have NASH). IR seems to be a common finding in NASH and it was described in $85 \%$ of the patients tested by Willner et al. [29]. IR plays a key role in the pathogenesis and development of NASH [30] Studies performed by Xanthakos et al. [27] and Finucane et al. [31] showed that HOMA -IR values were significantly different between obese patients with NAFLD and obese subjects without NAFLD. Chan et al. [28] had presented parameters of insulin sensitivity, including the HOMA index in 84 obese children, 65 of whom showed hepatic steatosis proven by ultrasonography. It was found that the severity of fatty liver was positively related to the HOMA index. Schwimmer et al. [32] screened 43 children with biopsy-proven NAFLD for insulin resistance and concluded that IR was correlated with the severity of liver histology. However, Eminoglu et al. [33] did not find any correlation between the presence and the severity of steatosis and the increased levels of HOMA -IR in their study. Radetti et al. [34] showed decreased insulin sensitivity in all of the obese children but no difference was found in insulin sensitivity between children with or without NAFLD.

The most important observation in the current study was the finding that serum osteocalcin level was significantly lower in the studied NAFLD patients, compared to those matched controls. Out of 60 patients, $42(70 \%)$ had low serum osteocalcin concentrations. Also, there was a parallel decrease in serum osteocalcin levels with increasing the grades of fatty liver infiltration as detected by ultrasound. Correlation analysis in the present study demonstrated that serum osteocalcin concentrations were inversely associated with HOMA-IR, fasting insulin, ALT and $\mathrm{W} / \mathrm{H}$ ratio in children with NAFLD. Previous data concerning estimation of serum osteocalcin levels in children still limited and controversial [35]. Yalmiz et al. [36] showed that serum osteocalcin levels were significantly lower in their biopsy proven NAFLD patients than in controls. Serum osteocalcin levels were inversely associated also with ALT, AST and HOMA-IR. The authors also demonstrated that serum osteocalcin concentrations are weakly, but significantly associated with the degree of hepatocyte ballooning, independent of other risk factors (including IR). As serum transaminases levels are conventionally believed to be surrogate biomarkers of hepatocyte injury, the association observed in our work and in other studies [36], seems to suggest that serum osteocalcin level may possibly reflect liver injury. However, we did not examine the severity of liver injury histopathologically among the ultrasonographic - proven NAFLD children.

In a study of 28 obese patients, Fernández-Real et al. [37] have shown that circulating osteocalcin concentrations are negatively associated with blood markers of liver injury and liver disease, including ALT and AST. In addition, the changes in ALT levels following weight loss in obese individuals were linearly associated with changes in osteocalcin concentrations. A Chinese adults study was consistent with our findings [38] reporting that serum osteocalcin levels were significantly associated with the scale of NAFLD. Osteocalcin showed a decreased trend with the scale of NAFLD. These results implied that osteocalcin could be a potential novel marker to assess the progression of NAFLD in children. In another study, Dou et al. [39] found that serum osteocalcin levels were significantly lower in subjects with NAFLD than those without NAFL. This study also showed that there was a statistical negative. Aller et al. [40] and Sinn et al. [41] studied the relation of osteocalcin with NAFL and found similar results. The observation that NAFLD patients with metabolic syndrome (MS) in this study had significantly lower levels of osteocalcin compared to those without MS is similar to that shown in adults e.g., Pittas et al. [42], Saleem et al. [43]. It is uncertain which mechanisms lead to lower osteocalcin levels in patients with NAFLD. Relying upon findings in patients with primary biliary cirrhosis and in patients with chronic alcoholic liver disease showing low serum osteocalcin levels [44], it is supposed that the chronic liver disease by itself can influence the osteoblast activity. One of the potential key contributor is the pro-inflammatory cytokine tumor necrosis factor- $\alpha$ (TNF- $\alpha$ ) that inhibits osteoblast differentiation and promotes osteoblast apoptosis [45]. An increase in circulatory level of TNF- $\alpha$ has been reported in NAFLD patients [46]. Additionally, the oncofetal fibronectin produced by activated star cells in chronic liver disease suppresses osteoblast function [47]. Consequently, osteocalcin synthesis is suppressed resulting in low serum osteocalcin concentrations in these patients. Previous studies have revealed that serum osteocalcin concentrations were positively associated with insulin secretion and inversely correlated with adiposity [35]. It has been suggested that decreased osteocalcin could lead to a worsening of liver fat infiltration in a vicious cycle. Insulin resistance (IR) might be the underlying mechanism linking the endocrine organ bone (osteocalcin) and liver lipogenesis.

Pomiedzy et al. [48] found that serum osteocalcin level decreases with increasing percentage of body fat and waist circumference as well as insulin concentration and HOMA-IR in obese children and adolescents. This observation indicates that osteocalcin acts as a negative regulator of fat mass and has favorable effects on fat and glucose metabolism in obese children. The present work and other 
related studies could suggest a novel cross - talk between bone and adipose tissue and liver. This association raises new prospects for future research in this area of work.

\section{Conclusion}

Our NAFL patients had significantly lower serum levels of osteocalcin compared to controls. Patients who had metabolic syndrome (MS) showed significantly lower serum levels of osteocalcin compared to those without MS. Serum osteocalcin levels were inversely correlated with the values of $\mathrm{W} / \mathrm{H}$ ratio, ALT, triglycerides, fasting insulin and insulin resistance (HOMA-IR) so serum osteocalcin levels were inversely associated with the degree of steatosis. So, osteocalcin is considered as a biomarker for severity NAFLD in children and adolescents.

\section{Recommendations}

Measurements of serum osteocalcin concentrations, as a marker of bone metabolism should be included among the biochemical tests performed in obese children and adolescents with NAFLD as the change in serum osteocalcin level was significantly associated with advancing liver fat infiltration.

\section{References}

1. Pardee PE, Dunn W, Schwimmer JB (2012) Non-alcoholic fatty liver disease in association with low bone mineral density in obese children. Alimentary Pharmacology \& Therapeutics 35: 248-254.

2. Lee NK, Karsenty G (2008) Reciprocal regulation of bone and energy metabolism. Trends in Endocrinology \& Metabolism 19: 161-166.

3. Ducy $P$ (2011) The role of osteocalcin in the endocrine cross-talk between bone remodelling and energy metabolism. Diabetologia 54: 1291.

4. Cole TJ, Bellizzi MC, Flegal KM, Dietz WH (2002) Establishing a standard definition for child overweight and obesity worldwide: international survey. BMJ 320: 1240 .

5. Krebs NF, Himes JH, Jacobson D, Nicklas TA, Guilday P, et al. (2007) Assessment of Child and Adolescent Overweight and Obesity. Pediatrics 120: S193-S228.

6. Egyption Growth Curves: Diabetes and endocrine metabolism. Unit Cairo University Children's Hospital. Available from: http: //dempuegypt.blogspot. com/ (Accessed on: 13 Aug 2009).

7. Fernández JR, Redden DT, Pietrobelli A, Allison DB (2004) Waist circumference percentiles in nationally representative samples of African-American, European-American, and Mexican-American children and adolescents. The Journal of pediatrics 145: 439-444.

8. Balistreri WF, Shaw LM (1987) Liver function. Fundamentals of clinical chemistry. 3rd edn. Philadelphia: WB Saunders, pp: 729-761.

9. Kith BT, Robert RT (2001) Lipids. In: Burtis CA, Ashwood ER (eds.), Tietz Textbook of Clinical Chemistry. 5th edn. WB Saunders Company, Philadelphia, USA 678: 750

10. Whelton A, Warson A, Robert C (1999) Glucose. In: Burtis CA, Ashwood ER (eds.), Tietz Textbook of Clinical Cchemistery. 3rd edn. WB Saunders Company, Philadelphia, p: 101.

11. Youcef G, Olivier A, L'Huillier CP, Labat C, Fay R et al. (2014) Simultaneous characterization of metabolic, cardiac, vascular and renal phenotypes of lean and obese SHHF rats. PloS ONE 9: e96452.

12. Henning B (1992) Method for the determination of osteocalcin in human serum or plasma. J Biol Chem 5: 168.

13. Chiloiro M, Riezzo G, Chiarappa S, Correale M, Guerra V, et al. (2008) Relationship among fatty liver, adipose tissue distribution and metabolic profile in moderately obese children: an ultrasonographic study. Current Pharmaceutical Design 14: 2693-2698.

14. Bedossa $P$ (2013) Current histological classification of non-alcoholic fatty liver disease: strength and limitations. Hepatol Int 7: 1-6.

15. Armitage P, Berry G, Matthews JNS (2002) Statistical methods in medical research. 4th edn. Oxford: Wiley-Blackwell 4: 125.
16. Patton HM, Sirlin C, Behling C, Middleton M, Schwimmer JB, et al. (2006) Pediatric nonalcoholic fatty liver disease: a critical appraisal of current data and implications for future research. Journal of Pediatric Gastroenterology and Nutrition. 43: 413-427.

17. El-Karaksy HM, El-Koofy NM, Anwar GM, El-Mougy FM, El-Hennawy A, et al. (2011) Predictors of non-alcoholic fatty liver disease in obese and overweight Egyptian children: single center study. Saudi journal of gastroenterology: Official Journal of the Saudi Gastroenterology Association. 17: 40.

18. Dasarathy S, Dasarathy J, Khiyami A, Joseph R, Lopez R, et al. (2009) Validity of real time ultrasound in the diagnosis of hepatic steatosis: a prospective study. Journal of Hepatology. 51: 1061-1067.

19. Brambilla P, Bedogni G, Moreno LA, Goran MI, Gutin B, Fox KR, et al. (2006) Crossvalidation of anthropometry against magnetic resonance imaging for the assessment of visceral and subcutaneous adipose tissue in children. International Journal of Obesity (2005) 30: 23.

20. Zimmet P, Alberti G, Kaufman F (2007) International diabetes federation task force on epidemiology and prevention of diabetes. The metabolic syndrome in children and adolescents. Lancet 369: 2059.

21. Duarte MA, Silva GA (2011) Hepatic steatosis in obese children and adolescents. Jornal de Pediatria 87: 150-156.

22. Papandreou D, Rousso I, Economou I, Makedou A, Moudiou T, et al. (2009) Is there any association between high-density lipoprotein, insulin resistance and non-alcoholic fatty liver disease in obese children?. International Journal of Food Sciences and Nutrition 60: 312-318.

23. Xanthakos S, Miles L, Bucuvalas J, Daniels S, Garcia V, et al. (2006) Histologic spectrum of nonalcoholic fatty liver disease in morbidly obese adolescents. Clinical gastroenterology and hepatology: the official clinical practice Journal of the American Gastroenterological Association 4: 226-232.

24. Sartorio A, Del Col A, Agosti F, Mazzilli G, Bellentani S, et al. (2007) Predictors of non-alcoholic fatty liver disease in obese children. European journal of Clinical Nutrition 61: 877-883.

25. Franzese A, Vajro P, Argenziano A, Puzziello A, lannucci MP, et al. (1997) Liver involvement in obese children. Ultrasonography and liver enzyme levels at diagnosis and during follow-up in an Italian population. Digestive Diseases and Sciences. 42: 1428-1432.

26. Tazawa Y, Noguchi H, Nishinomiya F, Takada G (1997) Serum alanine aminotransferase activity in obese children. Acta Paediatrica 86: 238-241.

27. Fu JF, Shi HB, Liu LR, Jiang P, Liang L, et al. (2011) Non-alcoholic fatty liver disease: an early mediator predicting metabolic syndrome in obese children? World Journal of Gastroenterology: WJG 17: 735.

28. Chan DF, Li AM, Chu WC, Chan MH, Wong EM, et al. (2004) Hepatic steatosis in obese Chinese children. International journal of obesity and related metabolic disorders: Journal of the International Association for the Study of Obesity 28 : 1257-1263.

29. Willner IR, Waters B, Patil SR, Reuben A, Morelli J, et al. (2001) Ninety patients with nonalcoholic steatohepatitis: insulin resistance, familial tendency, and severity of disease. The American Journal of Gastroenterology 96: 2957-2961.

30. Tilg $H$, Moschen AR (2008) Insulin resistance, inflammation, and nonalcoholic fatty liver disease. Trends Endocrinol Metab 19: 371-379.

31. Finucane FM, Teong L, Pittock S, Fallon M, Hatunic M, et al. (2008) Adverse metabolic profiles in a cohort of obese Irish children. Annals of Clinical Biochemistry 45: 206-209.

32. Schwimmer JB, Deutsch R, Rauch JB, Behling C, Newbury R, et al. (2003) Obesity, insulin resistance, and other clinicopathological correlates of pediatric nonalcoholic fatty liver disease. The Journal of Pediatrics 143: 500.

33. Eminoğlu TF, Çamurdan OM, Oktar SO, Bideci A, Dalgic B (2008) Factors related to non-alcoholic fatty liver disease in obese children. The Turkish journa of gastroenterology: the official Journal of Turkish Society of Gastroenterology 19: 85-91.

34. Radetti G, Kleon W, Stuefer J, Pittschieler K (2006) Non-alcoholic fatty liver disease in obese children evaluated by magnetic resonance imaging. Acta Paediatrica (Oslo, Norway: 1992) 95(7): 833.

35. Rochefort GY, Rocher E, Aveline PC, Garnero P, Bab I, et al. (2011) Osteocalcin-insulin relationship in obese children: a role for the skeleton in 
Citation: Ebrahim HT, El-Behery EG (2017) Osteocalcin: A New Biomarker for Non Alcoholic Fatty Liver Disease (NAFLD) in Children and Adolescents. Clin Med Biochem 3: 133. doi:10.4172/2471-2663.1000133

energy metabolism. Clinical Endocrinology 75: 265

36. Yilmaz Y, Kurt R, Eren F, Imeryuz N (2011) Serum osteocalcin levels in patients with nonalcoholic fatty liver disease: association with ballooning degeneration. Scandinavian Journal of Clinical and Laboratory Investigation 71: 631.

37. Fernández JR, Redden DT, Pietrobelli A, Allison DB (2004) Waist circumference percentiles in nationally representative samples of African-American, European-American, and Mexican-American children and adolescents. The Journal of Pediatrics 145: 439.

38. Liu JJ, Chen YY, Mo ZN, Tian GX, Tan AH, et al. (2013) Relationship between serum osteocalcin levels and non-alcoholic fatty liver disease in adult males, South China. International Journal of Molecular Sciences 14: 19782-19791.

39. Dou J, Ma X, Fang Q, Hao Y, Yang R et al. (2013) Relationship between serum osteocalcin levels and non-alcoholic fatty liver disease in Chinese men. Clinical and Experimental Pharmacology \& Physiology 40: 282.

40. Aller R, Castrillon JL, de Luis DA, Conde R, Izaola O, et al. (2011) Relation of osteocalcin with insulin resistance and histopathological changes of non alcoholic fatty liver disease. Ann Hepatol 10: 50-55.

41. Sinn DH, Gwak GY, Rhee SY, Cho J, Son HJ, et al. (2015) Association between serum osteocalcin levels and non-alcoholic fatty liver disease in women. Digestion 91: 150.
42. Pittas AG, Harris SS, Eliades M, Stark P, Dawson-Hughes B (2009) Association between serum osteocalcin and markers of metabolic phenotype. The Journal of Clinical Endocrinology \& Metabolism. 94: 827-832.

43. Saleem U, Mosley TH, Kullo IJ (2010) Serum osteocalcin is associated with measures of insulin resistance, adipokine levels, and the presence of metabolic syndrome. Arteriosclerosis, Thrombosis, and Vascular Biology 30: 1474-1478.

44. Szalay F, Lakatos $P$, Németh J, Abonyi M, Büki B et al. (1991) Decreased serum osteocalcin level in non-alcoholic and alcoholic chronic liver diseases. Orvosi Hetilap 132: 1301-1305.

45. Nanes MS (2003) Tumor necrosis factor-alpha: molecular and cellular mechanisms in skeletal pathology. Gene 321: 1.

46. Chu CJ, Lu RH, Wang SS, Chang FY, Wu SL, et al. (2007) Risk factors associated with non-alcoholic fatty liver disease in Chinese patients and the role of tumor necrosis factor-alpha. Hepato-gastroenterology 54: 2099.

47. Nakchbandi IA, van der Merwe SW (2009) Current understanding of osteoporosis associated with liver disease. Nature Reviews. Gastroenterology \& Hepatology 6: 660 .

48. Garanty-Bogacka B, Syrenicz M, Rać M, Krupa B, Czaja-Bulsa G, et al. (2013) Association between serum osteocalcin, adiposity and metabolic risk in obese children and adolescents. Endokrynologia Polska 64: 346-52. 